\title{
Forging socialism through democracy: a critical review survey of literature on Eurocommunism
}

\author{
Victor Strazzeri
}

\begin{abstract}
The article provides a critical overview of the latest phase of scholarly engagement with Eurocommunism, firstly, by pointing out the resilience of a 'Cold War framing' in many of the new studies of the phenomenon, secondly, by stressing the resulting blind spots in the assessment of its geographical scope (e.g., the lack of attention paid to Spain, scarce contributions on Eurocommunism's ramifications beyond West Europe). It then proposes a de-centred perspective on the phenomenon that is able to encompass its global roots and outreach, especially regarding the Third World; contrary to the prevalent focus on individual national cases of Eurocommunism, the article calls for a framing of Eurocommunist coordination as a transnational formation, so that both the leading role of Italian communists and the cross-border exchanges that shaped it can factor into a revised scholarly engagement with the topic. From this vantage point, Eurocommunism emerges as a strategy of transition for the global conjuncture of multiple crises that the 1970s represented, one that nevertheless failed to present a viable alternative to neoliberalism, another product of the decade in question. The article concludes by approaching the little explored gender dimension of Eurocommunism, visible in its entanglement with the second-wave feminism.
\end{abstract}

Keywords Eurocommunism; Cold War framing; 1970s crisis; Third World; feminism; neoliberalism

Twentieth Century Communism - Issue 17 


\section{Introduction}

urocommunism figures in the scholarship as a significant, if shortlived, phenomenon of 1970s West Europe: an outlier to bipolar logic unwittingly fostered by the brief respite in superpower rivalry known as 'détente'. It consisted in the coordinated attempt by major West European communist parties (CPs) to become credible alternatives of government, shedding the political outsider status ascribed to them within the prevailing Cold War framework. The formula employed to this end by its proponents - mainly the Italian, French and Spanish CPs [henceforth PCI, PCF, PCE] - placed democracy and pluralism at the centre of a reformed communist politics that distanced itself from the Soviet model yet still professed the aim of socialist transformation. As such, Eurocommunism aimed to constitute a 'third way' overcoming 'both the orthodox communist and the social democratic traditions' ${ }^{\text {in }}$ the 'context of the West'. 2

In his noted Moscow speech of November 1977, Enrico Berlinguer concisely stated the key components of the Eurocommunist formula and why it was an all-round geopolitical nuisance factor:

Experience has led us to the conclusion, as has been the case of other communist parties of capitalist Europe, that democracy is today not only the terrain upon which the class enemy is forced to retreat, but also the historically universal value upon which a novel socialist society is to be founded. ${ }^{3}$

By leveraging democracy as both a means of transition to socialism and as the political form of a fully constituted socialist reality, Eurocommunists did not so much mediate between the Cold War poles of capitalism and socialism as embody a critique of their foremost 'actually existing' representatives. The socialist society Berlinguer envisioned was novel due to its democratic constitution - i.e., it was imagined in contrast to extant models; but it was equally supposed to transcend present-day democracies, which still lodged the capitalist 'class enemy' in their entrails. 
If the Cold War was 'not solely a story of power dynamics', as recent scholarship has emphasised, but also 'a clash of ideologies, a battle for the future political and economic development of humanity', what distinguished the Eurocommunist proposition was its ostensible critique of the democratic shortcomings weighing on either side, i.e., the lack of political freedoms behind the 'iron curtain' and the social and global inequalities that plagued the 'free world'. ${ }^{4}$ This stance, which emanated from actors operating both within the 'West' and the international communist movement, held the potential to inspire a wide variety of actors in opposition to the bipolar status quo. Indeed, the appeal of Eurocommunism was inseparable from its framing of democracy; positing democracy as a 'universal value', gave it (potentially) 'universal appeal', at least in the sense of drawing adherents across Cold War divides during a time - the 1970s - marked by important realignments in the international order. 5

Eurocommunism's momentum was, however, not only a function of its status as an undesired consequence of détente or simply of its proponents' desire to bypass the ground rules for politics in the bipolar world. It had a range of domestic ramifications and its advent also marked the last peak of prestige and/or electoral success for the three major West European CPs. The PCF was up to the mid-1970s the main force of the left in France, consistently reaching around 20 per cent of the vote; its alliance with socialists, the 'Union of the left', almost elected François Mitterrand president in 1974; ${ }^{6}$ the PCI, which had attempted an alliance with Christian Democrats through the 'historic compromise' in 1973, reached over 34 per cent of the vote in 1976.7 The PCE, in turn, had established itself as the main resistance organisation to the Franco dictatorship $^{8}$ and, after abandoning armed struggle in the 1950s, became the key cog in the broad alliance that would spur Spain's transition to democracy in the mid-1970s. ${ }^{9}$ This renewed relevance in their respective national landscapes helped prop up Eurocommunism on the international stage for a time.

Faced with sudden decline in the early 1980s, the same parties dragged the Eurocommunist formula down with them. Crucially, 'it was not the collapse of the communist parties in Eastern Europe and the Soviet Union', as Charles S. Maier has stressed, 'that undermined 
the communist parties in the West'. A wider phenomenon was at play, namely, 'a more general loss of collectivist or leftist vision, East and West, during the 1970s and 1980s. ${ }^{10}$ A key contextual element for this shift is the global economic downturn that marked the period and the cycle of transitions and adjustments that it heralded. ${ }^{11}$ Eurocommunism was an ultimately unsuccessful attempt to reshape the political arena in response to this crisis scenario, much like the contemporary Third World uprisings and global feminist wave were attempts at radically reshaping centre-periphery and gender relations in its wake. As this essay will indicate, these trends not only inhabited the same world, they were interconnected. This wider embeddedness of Eurocommunism has, nevertheless, not been reflected in the research and my main goal in this critical review of the literature is to raise a few hypotheses as to why that has been the case.

Eurocommunism has been an object of research practically from the moment of its emergence. At its peak in the 1970s, Eurocommunism's combination of transversal repercussion in the global arena and immediate relevance at the national level quickly made it the subject of an abundant yet now mostly dated response from scholarship. ${ }^{12}$ The short lifespan of the phenomenon meant, however, that, despite the relative haste in the academic efforts to interpret it, much of the early literature surfaced as a key component of Eurocommunism - its transnational character - was no longer in play; by the end of the 1970s, the coordination between the main West European CPs had already broken down. The 1980s brought diminishing electoral results and the onset of decline (PCI, PCF) or terminal crisis (PCE) of the main parties involved, coinciding with a predictable drop in scholarly interest on Eurocommunism. Its three main organisations followed distinct pathways of decline/ transformation. The PCE imploded by the early 1980s, going from 'hegemony to self-destruction' in less than three decades. ${ }^{13}$ The PCI took the pathway of outright social democratisation and rejection of its communist legacy, symbolised by a name change in $1991 .^{14}$ The PCF, in turn, represents 'stasis' or a slow - though not always linear - decline, the product of societal shifts and overly timid efforts to adapt to them on its part, rather than of an ineluctable fate. ${ }^{15}$ All three cases have in common a precipitous fall in relevance and popularity. The late 1980s 
saw attempts at a more systematic appraisal of Eurocommunism that are still worth consulting, ${ }^{16}$ but the fall of the Soviet Union and the subsequent trajectory of what remained of the erstwhile Eurocommunist CPs (or their successor organisations) seemed to render moot the questions the phenomenon had raised. Significantly for this article, the retrospective projection of the post-1989 fate of these parties in interpretations of Eurocommunism - and the associated peril of a teleological analysis has loomed large over scholarship on the phenomenon since the 1990s.

By the middle of this decade, the 'third way' between Sovietstyle socialism and West European social democracy had become a no man's land. In fact, the term had since been appropriated by an entirely different political project, with which it is still associated, as large swathes of the left in the northern hemisphere attempted to work within the framework of neoliberalism by giving it a 'human face'. Symptomatically, an almost uninterrupted silence on Eurocommunism prevailed in the scholarship throughout the 1990s and up to the mid2000s, when a strong uptick in interest reversed this trend. ${ }^{17}$

This article aims to provide an overview of the latest phase of scholarly engagement with Eurocommunism, firstly, by pointing out the resilience of a 'Cold War framing' in many of the new studies of the phenomenon, secondly, by stressing the resulting distortions and blind spots in the assessment of its geographical scope. I then suggest a few pathways towards a new definition of Eurocommunism that, through a decentred perspective, considers its global roots and outreach, especially regarding the Third World. From this vantage point, Eurocommunism emerges as a strategy of transition for the global conjuncture of multiple crises that the 1970s represented. The issue of Eurocommunism's broadened stance on the revolutionary subject brings me, finally, to the little explored gender dimension of the phenomenon, visible in its entanglement with second-wave feminism. Based on the hypotheses raised in the last point, I will make the case for a new understanding of Eurocommunism as a key event of the world-making 1970s.

My goal with this intervention is not only to report on the current state of the research on Eurocommunism, but to open a discussion that transcends the framing of the phenomenon within national historiographies and prevalent patterns in communist history. My

Twentieth Century Communism - Issue 17 
purpose is, therefore, to inquire just how much our current grasp of Eurocommunism can gain new contours when its global scope as well as broader societal implications become a part of the picture. I believe the latest round of studies is substantial enough that a synthesis of the main trends (and gaps) that have emerged can be worthwhile. In a development consistent with its transnational scope, Eurocommunism has given rise to a body of literature spread across a range of scholarly landscapes. With this paper I thus also hope to contribute to a more unified conversation on the topic considering that, despite a relevant amount of publications in English, much of the historical literature has been produced in the former 'core' Eurocommunist countries of Italy, France and Spain - each with a peculiar slant connected to the legacy of the respective $\mathrm{CP}$ - followed by the German-speaking world and Latin America (especially Brazil and Mexico).

While the article stresses a few significant gaps in the scholarship, it does not compile an exhaustive list of research desiderata, which I believe only a collective effort can provide. The blind spots I highlight are, in turn, those specifically tied to deficits in the overall framing of Eurocommunism, above all, to how it is set against the background of the Cold War in the 1970s.

\section{The resilience of the 'Cold War lens'}

The reclamation of Eurocommunism as an object of research was fostered by the 1970s coming into view of historians, who were quick to point out the decade's central role in shaping the present world. ${ }^{18} \mathrm{~W}$ ithin this crucial juncture, Eurocommunism's failure has been framed as proof of the resilience of the bipolar system it had called into question and of the 'narrow political space for unorthodox movements, especially in the communist camp. ${ }^{19}$ This interpretation has been substantiated by detailed reconstructions of how the great powers, especially in the West, ${ }^{20}$ sought to contain the Eurocommunist 'threat ${ }^{21}$ and how, despite eliciting sympathetic views from actors as diverse as GDR authorities $^{22}$ and sectors of West European social democracy, Cold War loyalties ultimately prevailed. ${ }^{23}$ For, neither Soviet authorities desired 
the formation of an autonomous European pole within the international communist movement, nor did US leadership consider it acceptable that mass communist parties should come to power in Western Europe. ${ }^{24}$

Not surprisingly, this geopolitical constraint is understood to have largely sealed the fate of Eurocommunism. Indeed, the fact that the phenomenon occurred within the strategic theatre of Western Europe as well as within the political orbit of the Soviet Union not only did not open up a 'third way' for it, but made it especially vulnerable to the gravitational pull of the superpowers.

The key question for historical interpretation remains, however, to what degree the monumental cosmos of the bipolar world dictated the horizon of political life during the Cold War. While actors could not afford to ignore the existence of the bipolar international system, were they bound to appropriate the coordinates provided by this massive framework when seeking orientation for their political engagement? These questions translate, in turn, to a significant methodological dilemma, namely, if Cold War historians should take their bearings from an analytical compass structured along a dynamic of competing poles or whether it is possible to spatialise the period and the trajectory of its actors through non-binary frameworks.

The meticulously researched work of Nikolas Dörr on how U.S and West German authorities confronted Eurocommunism provides a fruitful example of how historians have sought to address these issues in the latest round of research on the topic. On the level of great power dynamics during the Cold War, the work is very illuminating. As a basis for a broader appraisal of the phenomenon, however, Dörr's vantage point shows clear limitations. 'In retrospect', suggests Dörr in the book's conclusion: 'the question arises as to what was the reason for the political and social mass interest that Italian Eurocommunism gave rise to from the mid to late 1970s'. The only major clue Dörr's investigation yields in this regard is establishing that there was palpable fear that Eurocommunism could become a 'valid strategy for all communist parties to come to power in Western states'. On this basis, Dörr concludes that ' $[\mathrm{p}]$ recisely because it was often perceived as a security threat did Italian Eurocommunism raise so much attention'. ${ }^{25}$ Dörr's 'top-down' framing of Eurocommunism is a clear reflection of the

Twentieth Century Communism - Issue 17 
standpoint of the high-ranking 'foreign and security policy actors' from the US, West Germany and NATO prevalent in his source-material ${ }^{26}$ - SPD records and those of the PCI play a more peripheral role in the study. While these are valid and revealing sources, a problem arises when their specific framing of Eurocommunism - i.e., as a 'security threat' 27 not only shapes the analytical approach but is projected onto the wealth of actors behind the 'mass interest' on the phenomenon. It is as if superpower competition structured the perception of political life within civil society at large in the same manner it did within the exclusive club of operators of great power politics and its dedicated observers in academia and the media at the time.

Dörr's study is but one (and indeed one of the better examples) of a series of research efforts to have heavily emphasised the response to Eurocommunism 'from above' - that is, from state actors, NATO etc. The resulting imbalance has meant that the standpoint of Eurocommunism's proponents themselves and the reception of their propositions 'from below', i.e., by rank-and-file communists and within social movements, have scarcely been addressed in the scholarship. ${ }^{28} \mathrm{I}$ attribute this to a stubborn resilience of the 'Cold War lens', which still refracts the interpretation of Eurocommunism and explains a range of distortions and blind spots in recent studies. ${ }^{29}$ This is particularly visible in how the geography of Eurocommunism has been drawn as of late. The spatial turn in historical scholarship notwithstanding, the latest round of research shows a general lack of reflection on this dimension of the phenomenon.

\section{The geography of Eurocommunism: from the 'West' as marker to 'Eurocommunist space'}

The question of just what is encompassed by the 'euro' in Eurocommunism represents an important analytical hurdle as the phenomenon was received and/or independently enacted beyond Europe from the very start. Accordingly, the early scholarship took the 'euro' to be relative and drew the scope of its outreach as far as the reform-oriented CPs of Japan and Australia. ${ }^{30}$ Some analysts even encompassed the cases of 
Mexico $^{31}$ and Venezuela, ${ }^{32}$ i.e., did not circumscribe Eurocommunism to the 'first world'.

If those efforts were very preliminary (a reformist impetus and willingness to engage with democratic politics was enough to ascribe CPs to Eurocommunism), there have been practically no further attempts to reconstruct the global outreach of the phenomenon. The latest scholarship, as Dörr has stressed, lacks 'publications on the transcontinental impact of Eurocommunism'. ${ }^{33}$ Indeed, recent transnational approaches have conceptualised Eurocommunism as having merely a trans-European footprint and, at most, transatlantic relevance, considering US authorities' steps to thwart the phenomenon.

I believe this narrowing of the spatial scope of Eurocommunism in current scholarship can be traced back to a tendency to closely embed the European space into the Cold War category of the 'West'. Indeed, the perception of the 'West' as a coherent, detached bloc, operating under a different logic than the rest of the world seems more ingrained in Eurocommunism's interpreters of today than in its observers from the 1970s. Symptomatically, it is the same Dörr that states:

...adding parties from 'Third World' states to Eurocommunism should generally be avoided, as they were not active within a Western environment and, therefore, lacked a primary defining characteristic of a Eurocommunist party. ${ }^{34}$

Dörr's statement comes as a surprise considering his own call for more studies on Eurocommunism's global impact. In their absence, how can a reliable basis for comparison between a 'European Eurocommunism' and its Third-World offshoots be consistently formulated? More telling, however, is the fact that Dörr makes this statement without providing any working definition of 'Western environment', which is taken as an unproblematic and readily understandable marker. As a result, the 'West', much as it was understood during the Cold War itself, not only silently provides the coordinates used to draw the geography of Eurocommunism, but more problematically, for how it is defined in the first place (Eurocommunism $=$ communist politics for a 'Western environment').

Twentieth Century Communism - Issue 17 
Understood as a political project and set of geopolitical alliances and not as a region on a map, the 'West' was indeed a key reality on the historical landscape of Eurocommunism. Just as thwarting the PCI's ascent to power in 1948 was one of the CIA's first tasks, ${ }^{35}$ the first ever meeting of the G7 in June 1976 had the ongoing economic crisis in Italy and the growth of the PCI at the top of its agenda. As Basosi and Bernardini have shown, not only did the great powers under renewed US hegemony, foreshadow the roll-back of Keynesian economic policy in West Europe during the summit (specifically in the liberalising conditions attached to the IMF loan to Italy), they also made 'communist non-accession to the Italian government' a 'basic precondition for providing the financial aid'. ${ }^{36}$ Eurocommunism, thus, emerged at a time when the 'West' as a transnational field of economic and political relations was being profoundly reconfigured. This new scenario was not simply unfavourable for the coordinated West European CPs; it was shaped by the great powers in direct opposition to the Eurocommunist programme and project of power.

Yet, it is not only the fact that the 'Western environment' was moving in a direction hostile to Eurocommunism that makes its identification with the 'West' vague and imprecise. If understood as a geographic manifestation of the advanced capitalist economies (the 'core' of global capitalism), which, on the basis of a Fordist arrangement, established welfare policies of various kinds, then the 'West' was not equivalent - or, to be more precise, isomorphic - with the scope of Eurocommunism. It was not a relevant phenomenon everywhere in the 'West'. Rather, it only gained traction where reform-oriented CPs had a mass base and drew legitimacy from antifascism and from the decisive participation in the postwar reconstruction of democracy (or, in the case of Spain, in spearheading the opposition to a long-standing dictatorship). As Ralf Hoffrogge has pointed out, in West Germany - where 'Western' conditions were no doubt present - the 'renaissance of leftist politics did not take place through a mass Communist Party, rather it brought about new political formations. ${ }^{37}$ 'Definition by location' proves inconclusive even with the added layer of specification that the three main Eurocommunist CPs were in Southern Europe or the Mediterranean space; as it happens, two of Eurocommunists' fiercest opponents within the communist 
movement were precisely the Portuguese and Greek CPs. ${ }^{38}$ The stance towards the Portuguese revolution was, in fact, an important point of contention between the PCI and PCF. ${ }^{39}$ Yet, the most significant issue with the conflation of Eurocommunism and a 'Western' context relates to the case of Spain. The dictatorship in the Iberian Peninsula was no doubt part of the geopolitical 'West', yet Franco's Spain neither boasted a fully-fledged advanced capitalist economy on a Fordist basis nor, evidently, was it a Welfare state democracy in the mid-1970s. The PCE's decided Eurocommunist turn took place while the party was still illegal, a status that lasted until April 1977; adhering to Eurocommunism was, in fact, part of its strategy to become a legitimate actor in the country's protracted transition to democracy. ${ }^{40}$

The conventional definition of Eurocommunism as a communist politics for advanced industrial democracies likely accounts for why most recent studies on the topic - in addition to the obligatory Italian reference - focus on French communists, ${ }^{41}$ widely recognised as reluctant adherents, ${ }^{42}$ yet omit the Spanish and wider global reception altogether. As E. Treglia has stressed, French and Spanish communists were almost permanently (and publicly) at odds after 1968, with the PCE striving for ever greater autonomy from the CPSU, and the PCF reverting to close alignment as early as 1969. This is also the context for the PCI's replacement of the PCF as the Spanish CP's closest ally in West Europe. ${ }^{43}$ In an example of how ingrained centre-periphery notions can eschew analysis even within a purely West European framing of Eurocommunism, only those scholars publishing in Spanish have given enough attention to the key role of the PCE and the fate of the Spanish transition for the phenomenon as a whole. ${ }^{44}$ As an adequate appraisal of the Spanish case demands a reworking of the commonly held definition of Eurocommunism, it represents one of the keys to a renewed understanding of the phenomenon. In other terms, because incorporating the Spanish reception into the trajectory of Eurocommunism necessarily negates the phenomenon's juxtaposition to an unreflected 'Western environment', it also opens up the door to an inquiry into its global roots and outreach (which scholars working on the PCE have, alas, also not attempted). Spanish communists turned to Eurocommunism for many of the same reasons Brazilian communists did; as both the PCE and the PCB aimed to build 
a broad oppositional front to dictatorial regimes, the Eurocommunist formula made it possible to frame the fight for democracy as coetaneous with the fight for socialism within a sole gradual process of transition. A 'Eurocentric' approach to Eurocommunism that places the Spanish and Brazilian experiences (a priori) on different spatial planes, has so far prevented historians engaging with such convergences.

In this sense, the problem with utilising essentialised spatial markers - like the Cold War notion of the 'West' - is that, in projecting political, economic and other social relations into a dead space, they also freeze them in time; they are thus more an obstacle than a viable pathway to demarcate the contours of a historical phenomenon. In this sense, it is Eurocommunism that can help historicise the 'West', and not the other way around. The existence of this phenomenon and its brief, but spectacular rise indicates that the role of West Europe in the bipolar framework was a contested one, especially in the period of global crises and realignments that the 1970s represented. What was at stake in the West Europe of those years was not just the drive towards integration, but also the region's position within the East-West axis and, not least, with regard to the Third World. The peculiar role played by reformminded CPs in this context cannot, therefore, be approached with reference to the dynamic of Europe alone.

Ultimately, by forging relationships and networks that prompted an array of cross-border transfers within and beyond the European setting and the bipolar order, Eurocommunists built a space, instead of simply being the product of one. The expanses of 'Eurocommunist space' have yet to be charted. If, like most transnational formations of the Cold War, Eurocommunism was characterised by both 'promise and fragility', 45 its promise has been systematically undervalued in the scholarship in light of its obvious fragilities. The recent detailed reconstructions of Eurocommunists' failures are no doubt a key step forward in understanding the phenomenon and the Cold War framework it was pitted against. Yet, without a fundamental reassessment of 'Eurocommunist space' the fresh scholarly interest on the topic risks remaining walledoff by the inherent biases of the 'Cold War lens'. A reassessment of the fundamental coordinates of Eurocommunism is thus a prerequisite for an appraisal of its impact and legacy beyond 1970s West Europe. 


\section{Coordinates for a new definition of Eurocommunism}

Opening the map of Eurocommunism creates, however, a host of issues regarding the definition of the phenomenon. No longer tethered to the 'West', the analytical perspective tends either to retreat to the individual national cases of Eurocommunism or, conversely, to grasp for a programmatic feature that would unite Eurocommunists everywhere, dissolving the phenomenon's specificity altogether. The latest literature on Eurocommunism has struggled with these limitations, as this section will show, but a number of contributions point the way to a revised definition able to work around them. Based on the latter, I will make the argument that, beyond a transnational formation emerging from the coordination of West European CPs, Eurocommunism was a) the product of a specific political tradition - the 'Italian road to socialism' - that went global starting in 1956; b) that it was, in essence, a strategy of transition for the crisis world of the 1970s; and c) that, as such, it aimed to coalesce a broad spectrum of revolutionary subjects alongside the working-class.

This 'updated' definition draws from attempts in the latest literature to convert Eurocommunism from label to a useful analytical category of historical research. The framing of space, as indicated in previous items, plays a decisive role and is a clear point of contention in these efforts. Nikolas Dörr, for instance, finds the transnational dimension of the phenomenon too diffuse to underscore consistent historical analysis. $\mathrm{He}$ correctly points out that, 'while the fascination with Eurocommunism might have been highly transnational, its unfolding took place mostly on a national basis'. With this premise in mind and after stressing the diversity of its national variants, Dörr chooses to frame his research subject as a 'specifically Italian Eurocommunism'. 46 If, however, there were as many forms of Eurocommunism as there were nationally distinct adherents to it, the question emerges as to what differentiated, for instance, 'Italian Eurocommunism' from Italian communism tout court. Finally, this solution only effectively applies to the PCI, in that it was the only representative of the coordinated West European CPs whose peculiar tradition had a direct connection with the Eurocommunist formula, for instance, in Togliatti's call for the conversion of the communist

Twentieth Century Communism - Issue 17 
movement into a 'polycentric system'. ${ }^{47}$ Conversely, it makes little sense to speak of a specifically French or Spanish Eurocommunism. The PCF and PCE each faced a domestic political reality with a different dynamic and, for various reasons, gave Eurocommunism a peculiar inflection, but that should not in itself inhibit the use of an umbrella term.

A better solution seems, instead, to characterise Eurocommunism as a transnational formation. Although the precise role of each CP and the degree of collaboration and exchanges between them is still an open research question, a transnational framing makes it possible, for instance, to ascertain a central Italian contribution to the origin and makeup of Eurocommunism without necessarily restricting the scope of the analysis to the Italian context. While a retreat to the national might provide firmer footing in terms of the sources, what sets Eurocommunism apart is precisely the heightened coordination and collaboration between West European CPs that it involved. The PCI openly framed its role in these efforts as part of a 'new internationalism', considering it went beyond previous cross-border bonds and took place in relative autonomy from Moscow. ${ }^{48}$ The explicit goal of this brand of communist internationalism was, however, to disseminate a specific programme (the 'peaceful road' to socialism) for a specific time (the crisis-ridden 1970s). To be clear, I employ the notion of 'transnational formation' to characterise Eurocommunism from the standpoint of historical inquiry, i.e., as an analytical category, therefore setting it apart from 'internationalism' or 'internationalist coordination', which is how CPs themselves termed their cross-border political strategy.

Yet, how can the call for a transnational framing of Eurocommunism accommodate the central role of Italian communists in the phenomenon? Several recent contributions indicate that the blueprint for the Eurocommunist formula originated from the cross-border or internationalist activities of the PCI on a much broader scale in the 1950s and 1960s. What emerged was a strategy of transition based on leveraging democracy as a tool of social change that was liable to be appropriated in various contexts. Finally, because it spoke to a conjuncture of crisis that was global in scale and to a set of emerging political actors that were not only present in West Europe, its impact goes beyond the final (and short-lived) uptick in electoral success and social prestige for 
European communism in the 1970s. Only a revised definition can make this visible; below are a few promising pathways in scholarship pointing towards one.

\section{a) The 'Italian road to socialism' and the Third World}

If the decisive contribution of Italian communists to Eurocommunism is one of the few points of consensus in the literature, what are the roots of this leading role and what elements can they provide for a new definition of the phenomenon? Studies on the cross-border activities of the PCI in the lead-up to Eurocommunism point to how Italian communists had become key international players even before its emergence. In fact, the prelude to Eurocommunism coincides with what could be termed the globalisation of the 'Italian road to socialism', i.e., with how, after the crisis year of 1956, Italian communists rose to become global actors by converting the PCI's program of a 'peaceful and democratic road to socialism' into a replicable revolutionary model they could export.

While scholarship has emphasised the better-known cases of China $^{49}$ and Cuba, ${ }^{50}$ a growing number of studies indicate that the PCI also attempted to fashion their own peculiar 'road to socialism' into a viable blueprint for Third World revolutions. In a postwar situation with several incumbents aiming to recapture the 'charisma of world revolution'51 - an erstwhile central component of Bolshevik power that, by 1956, had been all but abandoned in favour of Soviet raison d'état ${ }^{52}$ - the last Togliatti displayed a keen awareness for the growing centrality of the Third World to global politics. ${ }^{53}$ Concluding that Moscow was not doing enough to provide an alternative model for social change in the Third World in light of the challenge of the Chinese, ${ }^{54}$ the PCI 'pivots' South, projecting its prestige and tradition on the global stage from Africa ${ }^{55}$ to Latin America, ${ }^{56}$ in the name of the 'peaceful road to socialism'. ${ }^{57}$ It is also within this framework that the PCI links up with the Non-Aligned Movement and, especially, Yugoslavia. ${ }^{58}$

It seems these developments created two preconditions for the PCI's subsequent leading role in Eurocommunism: a global protagonism that

Twentieth Century Communism - Issue 17 
did not strictly orbit the Soviet Union and the party's identification with a project of peaceful - or non-insurrectional - transition to socialism. These were, naturally, not the only preconditions for the Italian role in the coordination of West European CPs; the prestige drawn from the PCI's participation in the anti-fascist resistance and in the subsequent construction of the Italian republic, its mass character and, finally, its association with the person and (a certain reading of) the work of Antonio Gramsci were all instrumental in lending credibility to its programme of fundamental, yet gradual, social change, whose main lever was expanding democracy.

Yet, only a consideration of the PCI's significant global engagement can explain why, for instance, a founding document of this programme - and of Eurocommunism itself - is an article about Chile. Enrico Berlinguer's Considerations on Italy after the coup in Chile shows just to what extent global context and domestic politics were intertwined in the thought-world of the PCI of the 1970s. The case of Italian communists' bond with Salvador Allende's Popular Unity government in Chile is the clearest example of a relationship with a Third World actor that was based on solidarity and support but was not limited to a one-way affair. As Berlinguer's reaction to the September 1973 coup demonstrates, it also involved a strong component of identification:

The events in Chile were experienced... as a tragedy by millions of people spread across all continents. It was and will continue to be regarded as an occurrence of global significance, which not only elicits feelings of revulsion [...] and of solidarity with those that fell victim to it and resist it, but also raises questions that compel all those that struggle for democracy in every country to reflect. ${ }^{59}$

The events in Chile were perceived not only as the catastrophic defeat of an ally in a context far-removed from West Europe, but as a direct blow to Italian communists' own political project. It is in this series of articles that Berlinguer first articulated the 'historic compromise', i.e., the willingness to forge an alliance with Christian Democrats both to safeguard Italian democracy and as a step towards a broad popular coalition for social progress 'on the road to socialism'. While the coup in Chile did 
not cause the PCI's change of course, it is nevertheless striking that an event across the Atlantic provides the occasion to announce it. The relationship between the PCI and Chilean politics is indeed a complex case of transnational entanglement. ${ }^{60}$ It went further than the status of the Chilean Popular Unity experiment (1970-1973) as a living model for the 'peaceful road to socialism' championed by the PCI; Chilean communists had been actively supported by their Italian comrades since the late 1950 s and especially through the 1960 s, i.e., long before they came to power alongside the socialist Salvador Allende in 1970.61 The connection with Chile is, rather, evidence of a much broader reorientation of Italian communism than the Eurocommunist formula is conventionally thought to imply:

The depth of the bond uniting the party of Botteghe Oscure and the Chilean experiment can only be understood if one takes into account how the latter overlapped and combined with a number of other phenomena which had enormous repercussions on the identity of the PCI... they broke open the elementary coordinates of a thought-world centered on the combination of working class and Soviet Union, which had characterised their utopia until the 1950s. ${ }^{62}$

In a way, then, to become a central player in European communism, the PCI had first to overcome its 'traditional eurocentrism'. ${ }^{63}$ It is thus the destruction of Chilean democracy that, paradoxically, signals the need to shift the focus of international activities towards a West European setting perceived to be in line for a similar fate, thus sparking the Eurocommunism coordination. This assessment does not invalidate attempts in the recent scholarship to frame Eurocommunism as a form of communist 'Europeanism' i.e., as part of the broader effort at forging Europe into an autonomous player in the global arena that found adherents across the political spectrum at that juncture. Eurocommunism did coincide with a shift in Italian communists' stance towards European integration, from 'opposition to euphoria'. ${ }^{64}$ Eurocommunist Europeanism was, however, interwoven with a strong element of Third-Worldism ${ }^{65}$ and aimed to 'redefine the terms of North-South rela-

Twentieth Century Communism - Issue 17 
tions' ${ }^{66}$ This helps explain why 'there is scarcely a solemn occasion in the life of the party' in which Enrico Berlinguer 'did not take a stance on the fortunes of the Third World and the newly-independent countries'. ${ }^{67}$ Silvio Pons termed this the 'universalist mission' inherent to the 'Eurocommunist formula'. ${ }^{68}$ A universalism that encompassed both the efforts to globalise the 'Italian road to socialism', but also a keen awareness, as articulated by Berlinguer, of the 'liberating and stimulating effects that can derive - indeed have already derived - from emancipatory processes of the Third World' for the European context - a remark made in reference to the roots of the Carnation Revolution in anti-colonial struggles in Africa. ${ }^{69}$

As a final note, it is worth mentioning that long before scholarship drew attention to what I have termed the globalisation of the 'Italian road to socialism', i.e., the augmentation of the cross-border relevance of the Italian communist tradition in West Europe and beyond, it was recognised in its broad outlines by an enthusiastic Third-World adherent of Eurocommunism. In a 1979 essay titled 'Democracy as a universal value', Carlos Nelson Coutinho, an intellectual of the Brazilian Communist Party [PCB] that had spent part of his exile in Italy in the late 1970s, drew a novel interpretation of Berlinguer's epithet from his Moscow speech. Coutinho believed it to be valid not only in West Europe, but also across the Atlantic:

This universality should not be conceived in a merely theoretical sense; nor is the value of democracy limited to certain geographical contexts. For if there is a universal element in the theoretical reflections and political praxis of what is today called Eurocommunism, it is precisely the new way... it conceives the relationship between socialism and democracy. ${ }^{70}$

Within the context of Brazil's transition to democracy in the 1980s, the essay has been called a 'true watershed for the Brazilian left'. ${ }^{71}$ As I stressed above, similarly to the case of Spain, Brazilian communists saw Eurocommunism as a formula to convert the transition to democracy in a country still ruled by a dictatorship into the first step on the pathway to socialism. The next item approaches what lent credence to this possi- 
bility - thus putting wind in Eurocommunism's sails - in a variety of contexts in the 1970s.

\section{b) The 'shock of the global' and the search for a 'third way' in the 1970s}

If Eurocommunism is a strategy of transition rooted in the Italian communist tradition and stemming from the coordination of West European CPs (but applicable beyond Europe), it is indissociable from a specific global moment marked by multiple crises in which such a transition was regarded as a real possibility. In addition to the mostly overlooked peak 'impact of the Third World on Western Europe', ${ }^{72}$ Eurocommunism was the product of a scenario of economic crisis in the 1970s which signalled in the eyes of its proponents an open avenue for programs of socialist transition. The antediluvian character of this horizon of possibility - which did not close as much as slam shut in the 1980s - likely explains the difficulty for historical narrative today to restore it as a key driver of Eurocommunism.

Part of the reason is, once more, the tendency to frame the role of global processes strictly from the standpoint of its national ramifications. Thus, even those studies that point to the global economic crisis of the 1970 s as a key contextual element for Eurocommunism have downplayed the weight of cross-border factors in its trajectory. Basosi and Bernardini, for instance, have pointed out how 'Eurocommunism's steep parabola simply paralleled the rise and fall of the PCI's electoral performance', which they ascribe to:

positions actually taken by its leadership in the Italian context during the crucial period 1976-78, rather than to philosophical disputes about the possibility of finding the desired 'third way' between Soviet communism and Western European social democracy. ${ }^{73}$

Yet, are missteps in the domestic arena and the failure to forge a 'third way' necessarily self-excluding causes for the decline of Eurocommunism?

Twentieth Century Communism - Issue 17 
Basosi and Bernardini themselves stress how the new context created by the global economic downturn of the 1970s played a decisive role in the Italian conjuncture and how it was ultimately the failure of the PCI to provide a consistent alternative to the crisis that led to its subsequent decline in popularity ${ }^{74}$. The search for a 'third way' by West European communists was, in fact, intrinsically linked to the crisis, which both raised the question of power anew and cut through the various national contexts where 'reform communism' played a relevant role.

The significance of the crisis was noted at the time both by actors and observers of Eurocommunism. In December of 1974, Berlinguer termed it a 'deep crisis of a new type', one that went beyond 'cyclical crises' as it 'affects all areas - the economy, politics, culture - and manifests itself both internally in each country and in international relations' ${ }^{75}$ Fernando Claudín, in turn, drew attention to how the global crisis of capitalism was 'acting as a great orchestra conductor' by synchronising the distinct social and political processes affecting the three core Eurocommunist countries as well as elevating the degree of influence they could exert on one another. ${ }^{76}$ Furthermore, as one recent analyst has pointed out, 'in Italy, Spain and France, the profound social and economic crisis coincided with the crisis of their respective political systems. ${ }^{77}$ In fact, despite their differences, both the Italian Republic and the French Fifth Republic saw major shifts in their respective party landscapes at the time; Spain, in turn, saw the onset of its transition to democracy. Crucially, West European communists and other left-wing forces felt poised to take the political initiative within this context. In the words of PCE historians Carme Molinero and Pere Ysàs:

The pathway to a democratic socialism seemed open by a combination of the capitalist crisis, the strength of the labor and popular movements and of left-wing parties as well as the vitality of democratic institutions. ${ }^{78}$

Silvio Pons has similarly drawn attention to Berlinguer's relatively optimistic assessment of the turbulent global conjuncture of the 1970s; while the leader of the PCI did not rule out an authoritarian shift in Europe as 
a response to the crisis, he ultimately believed it also offered a window of opportunity:

At his confidential meeting with Leonid Brezhnev, the general secretary of the CPSU, on March 1 [1976], Berlinguer emphasised the 'new possibilities' arising from the 'democratic and socialist forces' in a situation marked, in his opinion, by the decline of the United States after its defeat in Vietnam and by the crisis of capitalism in Western Europe. ${ }^{79}$

For a time, the mounting crisis of capitalism and the growing electoral success of the PCI 'seemed to lend weight to Berlinguer's strategy' ${ }^{80}$ The protagonists of Eurocommunism had indeed accurately sensed there was an epochal shift in progress; they, however, fatally misjudged its general tendency. What the crisis context of the mid-1970s gave rise to was not democratic socialism, but neoliberalism. ${ }^{81}$ In fact, Eurocommunism and neoliberalism turn out to be radically opposite solutions to the same crisis scenario; where the former failed, the latter took hold.

Eurocommunists did not factor in such an outcome as possible in their political calculations; they believed a conservative alternative to their program would be more akin to the coup in Chile in 1973, i.e., would very likely mean the destruction of democracy (or, in the case of Spain, the failure to overcome dictatorship). That a sustained attack on welfare systems and a surge in the concentration of wealth and income at the top of the social pyramid would be possible without doing away with the democratic institutional order on the national level is something that would start to become evident only by the end of the decade, as neoliberalism gained consistency as a platform and reaped electoral victories in major contests.

This failure of foresight explains a range of fateful miscalculations. As the question of a loan to Italy emerged during the Andreotti government in 1976, PCI leadership chose to garner credibility in the eyes of domestic elites and US authorities through an 'acquiescent attitude on the IMF clauses', as opposed to addressing those 'demands for social justice that had been at the root of its earlier success'. ${ }^{82}$ It is in this context that Berlinguer comes out in favor of austerity, attempting to give it a left-wing, vaguely anti-capitalist connotation. ${ }^{83}$

Twentieth Century Communism - Issue 17 
Thus, with the post-war order social democracy had helped forge in disarray and the USSR less and less a beacon of hope to CPs increasingly critical of it, finding a 'third way' was anything but a philosophical dispute. The attempt to trail it, nevertheless, only makes sense against the background of the general crisis of the 1970s, which gives Eurocommunism its specific historical time; one framed, respectively, by the aftermath of the global 1968 and the beginning of the fall of communism in 1989.

Setting Eurocommunism within a clearly defined historical frame is an important steppingstone towards a new definition. For, if a retreat to the national variants of Eurocommunism can result in losing sight of its key transnational dimension and global context, the attempt to sever the definition from a concrete space-time, is even more of an analytical dead-end. An example pertains to the centrality of democracy, both as a means for the transition to socialism and as its desired political form. While it certainly unites Eurocommunists across national contexts, if taken in isolation, it makes the West European CPs of the 1970s indistinguishable from the pre-1914 SPD's revisionist wing, Austro-marxists, popular-front communists and any other attempt to leverage democracy as a pathway to and - in its 'fully-fledged' form - as the embodiment of socialism, all the way to present-day Spain's Podemos. ${ }^{84}$

A similar issue emerges when distancing or disobedience towards Moscow is the yardstick in question. Once again, while greater autonomy and the willingness to subject Soviet policy or its model of socialism to critique were traits that united all Eurocommunists, not only did Western European CPs distance themselves to different degrees from the USSR - from timid and hesitant disagreement (PCF), to consistent critique though not to the point of a break (PCI), all the way to bordering on full rupture (PCE) -, they were not the only dissenting voices in the international communist movement. In the European context, this trait extended, for instance, to the Yugoslav Communist League and the Romanian ruling $\mathrm{CP}$ under Ceauşescu. As mentioned above, Yugoslavia's connection to Eurocommunism is a relevant one due to the role played by the rebel socialist state in challenging the bipolar framework. The case of Romania, which directly supported Eurocommunist parties, ${ }^{85}$ shows, however, that isolated criteria such 
as 'autonomy from the USSR' can lead to radically inconsistent ascriptions. ${ }^{86}$ The solution I suggested above, i.e., defining Eurocommunism as a strategy of transition, rules out the inclusion of ruling parties in socialist states within the scope of the phenomenon. Yet, the conceptualisation of Eurocommunism must also be able to account for the influence and impact of actors and events in the socialist world in its trajectory.

The most consistent effort in this regard in the recent literature was made by Pons and Di Donato, who frame Eurocommunism as a chapter of 'reform communism' understood in the broad sense, i.e., as a link between the Prague Spring of the late 1960s and perestroika in the late1980s USSR. ${ }^{87}$ This view emphasises Eurocommunism's transnational entanglements with the East, linking the phenomenon with critical stances on Soviet communism from within the 'iron curtain'. ${ }^{88}$ This framing raises fertile research questions, especially regarding the possible impact of Eurocommunism as inspiration for the Gorbachev-led efforts at reform of the USSR. ${ }^{89}$

This assessment also neatly closes the circle of transfers and exchanges between the West European CPs, on the one hand, and the reform attempts in the European socialist states that set off from 1956 and reach a high point in 1968, on the other. As a number of studies have shown, the majority of the West European CPs openly manifested their disagreement with the intervention of Warsaw Pact forces in Czechoslovakia ${ }^{90}$ and, while this rang louder in the case of the Italian and Spanish CPs, ${ }^{91}$ it did not exclude the more closely aligned PCF. According to the research, the ascent and repression of the Prague Spring contributed to the later emergence of "Eurocommunism" in two ways: it catalysed the tendencies for autonomous action that were already present for some time within many CPs of West Europe and beyond and, secondly, it spurred an immediate call for more cooperation between them, with the PCI in the lead. ${ }^{92}$

Yet, what the latest studies on the impact of the events of 1968 in Prague on West European CPs have also established is the fact that the connection between the critical stance these parties took on in the aftermath of the intervention and their later turn to Eurocommunism was not a direct or straightforward one. ${ }^{33}$ As Maud Bracke has stressed,

Twentieth Century Communism - Issue 17 
besides the fact that 'the links between the two events are taken for granted or are not specified', the direct link thesis fails to explain the gap represented by the extended 'phase of realignment initiated in late 1968 up to the early $1970 s^{9} .^{94}$

In this sense, though the impact of the Soviet intervention in Czechoslovakia was no doubt a key moment in the pathway to Eurocommunism, ${ }^{95}$ other key occurrences from the same period, especially the French '68 and Italian 'hot autumn' of 1969, must be added to the narrative, even if the PCF and PCI were not - at least initially relevant players in either case. ${ }^{96}$ The eruptions of the global ' 68 hit close to home and, indeed, led to significant aftershocks in the major West European CPs, which were no less challenged by these events than the postwar status quo sixty-eighters aimed to radically transform.

\section{c) Eurocommunists and the aftermath of 1968}

Taking stock of the recent literature on the global 1968, Odd Arne Westad drew the somewhat surprising conclusion that 'the biggest political change of the time' was actually 'the reorientation of the largest Western European communist parties toward democratic participation and parliamentary strategies. ${ }^{97}$ Yet, Westad argues, much of the New Left that emerged from the 1960s did not engage with the phenomenon, because they 'found it easier to idealise far-away rebel groups than to work with the traditional Left of their own countries'. In fact, the only forces emerging from the 1960s rebellion that were able 'to overcome political and social divisions and thereby lay the foundation for long-term change' were 'the women's movement and the civil rights movement in the United States. ${ }^{98}$

While Westad is correct to point out the fundamental gap separating New Left organisations and movements from the more 'traditional' left-wing forces they aimed to overcome, a closer look at the interactions of Eurocommunist CPs and the 'new social movements' shows a more complex and entangled relationship. Especially in the case of one of Westad's few enduring offshoots of 1968, the women's movement, research has begun to uncover not only active cooperation, but an at 
times intense - if far from harmonious - overlap with reform communism, even if a lasting synthesis ultimately failed to materialise.

Once again, it is the limited scope of the conventional definition of Eurocommunism - alongside the deep-seated notion that, as supposedly antagonistic phenomena, the communist movement and 'new social movements' are topics for different experts, if not disciplines - that has prevented more studies into its gender dimension and impaired the reception of those efforts that have tackled the issue. As in the previous items, my goal here is not to refute prevailing definitions of Eurocommunism, but rather to widen their scope and sharpen their focus through a brief reconsideration of the latest research.

Eurocommunism has, for instance, often been defined by the expanded alliance policy its protagonists engaged in. Taken in isolation, this trait again makes the phenomenon indistinguishable, for instance, from the popular-front politics of the 1930s; on the other hand, an overly narrow understanding of these novel alliances sees the three main Eurocommunist CPs attempting to converge with a different set of forces in each case - Christian Democrats in Italy, socialists in France and forging a broad democratic front in Spain. By adjusting the notion of expanded alliances to encompass other political and social subjects beyond the working class, as opposed to relating it strictly to political parties beyond the communist tradition, not only does Eurocommunism's gender dimension and interactions with a resurgent feminist movement enter the picture, this recalibration further contributes to situating the phenomenon historically, considering the 1970s were also the decade of a global feminist upsurge.

This is not an entirely new angle on the topic. A few dissenting voices in the scholarship had indeed previously suggested that the relationship between Eurocommunism and 'new social movements' was a relevant one and merited further study; Geoff Eley, for instance, stressed in the early 2000s that, in addition to 'breaking with the USSR' and embracing 'pluralism [and] multiparty competition',

Eurocommunists prioritised issues that couldn't be subsumed within class-struggle perspectives based on the working class. [...]

Twentieth Century Communism - Issue 17 
These departures converged with the legacies of 1968, for which Eurocommunism became a main conduit to the party system. ${ }^{99}$

This understanding of Eurocommunism is significant not only because it radically breaks with the Cold War top-down framing of the phenomenon, but because of its implications with regards to a much broader issue: it might uncover an instance where the gulf conventionally thought to separate a 'politics of class' and a 'politics of gender' was demonstrably bridged.

The Italian case is a particularly fertile testing ground for this hypothesis. ${ }^{100}$ As Maud Bracke has stressed, despite being known as the 'years of lead', 1970s Italy actually saw 'high-levels of social participation', peaking precisely in the 'campaigns around divorce and abortion'. ${ }^{101}$ The PCI was not only active in both campaigns it was the most important force within the party spectrum to campaign for a 'no' vote in the divorce referendum of $1974^{102}$ and to push for the approval of legislation legalising abortion, culminating in the passing of Law 194 of $1978 .{ }^{103}$

Yet, because the importance of the women's movement to this period has not been adequately reflected in historiography, the question of its overlap with Eurocommunism has barely been raised. In the Italian case, the dynamic behind the formation of this blind spot is clear. According to Bracke, '...political histories of 1970s Italy... have generally been unable to grasp the central role played by women and feminism in the dramatic transformation of Italian society and politics in this period'. ${ }^{104}$ Crucially, this transformative role also extends to communist politics, as visible in the transition of the PCI-aligned women's organisation, the Unione Donne Italiane (UDI), to a much more autonomous and combative stance over the course of the 1970s, when it incorporated many perspectives from contemporary feminist groups. ${ }^{105}$ Galvanised by the transformations in the UDI and the aforementioned campaigns, the PCI's female members increasingly demanded a larger role in the party, compelling it to give greater attention to the 'women's question', even if further research is needed to ascertain just how far it went in this direction. ${ }^{106}$

As for Eurocommunism, leading female activists of the PCI understood the growing centrality of feminist issues to party debate and policy 
as an integral part of the change of culture it embodied; they were also quick to recognise that this dimension of the Eurocommunist turn would likely be downplayed or outright ignored in mainstream debate. In the preface to a still very readable and revealing volume of interviews with female activists of the PCI published in mid-1979, Laura Lilli gives a novel interpretation of the Eurocommunist notion of a 'third way'. Lilli argued the term also expressed the pathway communist women took to address the issue of 'double militancy', i.e., the possibility of simultaneous activism in the PCI and feminist groups (double militancy had always been taboo in communist politics). By securing the consent of the party to be active in both the institutional and extra-parliamentary left, communist women had introduced 'a further, original Italian attempt at a "third way"', one that was, 'of course, systematically disregarded by "political scientists".' 107 The advent of 'double militancy', Lilli concluded, indicated that the Eurocommunist third way was not limited to the 'ideological, economic or diplomatic' spheres; 'nor did it regard only great power "structures" and policy'; 108 it also pertained to 'the everyday dimension of our existence.'109

Feminism had revealed that the experience of hardship and oppression women experienced in everyday life was every bit as political as the causes around which both the 'old' and 'new' left were organised. 'Feminism is thus as political as all the anti-authoritarian movements underway in the world today', argued Carla Ravaioli, in the preface to another interview volume, this one pitting the PCI's (male) leaders, from Napolitano to Berlinguer, with the 'women's question'.110 For many women in 1970s Italy, this assessment did not mean turning away from the communist party; rather - and no doubt as a result of the promise of renewal represented by Eurocommunism -, many entered the PCI precisely in this juncture, often after disappointing experiences with the patriarchal nature of the small leftist groupings that emerged in the context of the 1968 moment.

These developments characterise what Maud Bracke termed the 'process of post-1968 re-institutionalisation', whereby there was a 'transfer of political agency by social movements to the political parties and state institutions which they had previously contested, specifically the PCI'.111

Twentieth Century Communism - Issue 17 
What drove this process was an understanding of feminism as part of the general 'assault on the vertical and class-based structure of society', in the words of Ravaioli; despite conceding that the 'primary and politically "proper" expressions' of this assault were 'class struggle' and 'Third-Worldist insurrection' and that every distinct movement was a manifestation of subjects 'with specific problems, demanding specific analyses and tactical choices', Ravaioli maintained they were 'all recognisable as a kind of "plural subject", in one and the same struggle against capitalism and the ideology that sustains it'. ${ }^{112}$ This unifying viewpoint constituted an attempt to express conceptually, what was a growing articulation between communist militancy, new social movements and wider global trends in 1970s Italy. Especially for women activists, this synthesis was what Eurocommunism was primarily about, something the scholarship has failed so far to appraise systematically.

In her 1979 review of Lili and Valentini's interview volume, Rossana Rossanda - a member of the PCI until she was expelled alongside the $I l$ Manifesto group in 1969 - shows this understanding of Eurocommunism was not exclusive to its membership. Rossanda remarked how the interviews 'suddenly made plain the decade of distance separating her time in the party' and how they brought home just 'how the fabric of the PCI had changed in the 1970s'. As a party dissident, Rossanda was not one to spare the PCI of critique, but perhaps for this very reason she was able to devise the true content of the process of renewal heralded by Eurocommunism, doing so against the common wisdom - then and now - on this matter. 'These changes', she remarked, 'were not explainable with the overcoming of the ambivalences from Togliatti to Berlinguer', rather, they resulted from

the overlapping of the political shift of the historic compromise and the mass movement, from which the PCI extracted its political capital between 1968 and 1975; a movement which, having shattered itself on the cliffs of the New Left, but still full of impetuousness, found its way to the party bestowing it with antagonistic and radical traits. ${ }^{113}$ 


\section{Conclusion}

The goal of this article has been to produce a review of the latest literature on Eurocommunism that compiles the main results achieved but does so 'against the grain' - i.e., providing a critical examination of some of the chief trends in how the phenomenon has been framed. This effort has led to the suggestion of a few key coordinates for a renewed definition of Eurocommunism. Fundamental to it is the notion that most current takes on the phenomenon need an urgent 'de-centring', that is, a framing that considers the global context of the Eurocommunist formula beyond a strict view of bipolar rivalry, thus incorporating the key role of the Third World into the analysis and taking into account actors not usually considered relevant to communist politics.

This call to 'provincialise' Eurocommunism is no doubt inspired by current debates in historiography and society at large but is no less a way to reconnect with the way actors themselves engaged with the phenomenon in the 1970s. Thus, while it might seem self-evident to emphasise the role of the bipolar system in the trajectory of a phenomenon such as Eurocommunism, with insights from postcolonial and feminist perspectives a seemingly anachronistic projection of current issues and analytical trends, the argument I want to close this literature review with is that precisely the opposite is the case. Without downplaying the role of the superpowers in containing and limiting the possibilities of success of the Eurocommunist CPs, it is the 'Cold War lens' and the associated notion of a self-encapsulated 'West' that upon closer examination emerge as the actual projections of contemporary analysts onto their source material, resulting in an overly narrow picture of Eurocommunism as a historical phenomenon. On the other hand, a provincialised view of Eurocommunism that emphasises the role of transfers and connections with the Third World appears to be more consistent with the way its own purveyors and supporters saw the world, even if this might seem counterintuitive today; gender, in turn, equally emerges as an entirely neglected driver of Eurocommunism, once the overlap between the communist and feminist movements are at all considered by scholarship.

This hypothesis - raised here in a necessarily shorthand form - is an effort to further stimulate the debate on Eurocommunism, one dating

Twentieth Century Communism - Issue 17 
from the very emergence of the phenomenon; a decade of resurgent scholarship on the topic and a steady stream of publications that shows no signs of tapering off, has prepared the ground for exciting open avenues of research, some of which this essay touched upon, but of which there are surely many more. ${ }^{114}$

The author would like to thank Brigitte Studer, Sandrine Kott, Andrew Zimmerman, Stefan Berger, Geoff Eley, Carme Molinero, Katherine White and Victor Neves for their contribution to the research that went into this article.

\section{Notes}

1 Silvio Pons and Michele Di Donato, 'Reform Communism' in Juliane Fürst, Silvio Pons and Mark Selden (eds), The Cambridge History of Communism, v. 3, Cambridge, Cambridge University Press, 2017, p192.

2 Nikolas Dörr, Die Rote Gefahr. Der italienische Eurokommunismus als sicherheitspolitische Herausforderung für die USA und Westdeutschland 1969-1979, Köln, Böhlau, 2017, pp50-1.

3 Enrico Berlinguer, 'La democrazia è um valore universale' (1977), in Leonardo Raito (ed), Enrico Berlinguer e il sogno eurocomunista, Rovigo, L'Arca, 2013, p39.

4 Jeremy Friedman, Shadow Cold War: The Sino-Soviet competition for the Third World, Chapel Hill, Univ. of North Carolina Press, 2015, p19. Odd Arne Westad has also drawn attention to the ideological contest at the core of the Cold War: see The Cold War: a world history, New York, Basic Books, 2017, pp19-42.

5 See Maud Bracke, Which Socialism, Whose Détente? Budapest/ New York, Central European University Press, 2007 and Valentine Lomellini, 'A window of opportunity? Eurocommunism(s) and détente' in Elena Calandri, Daniele Caviglia, Antonio Varsori (eds), Détente in Cold War Europe: Politics and Diplomacy in the Mediterranean and the Middle East, London, Tauris, 2012, pp71-92. Focusing on détente as its key contextual element, Frédéric Heurtebize has emphasised 
Eurocommunism's status as 'an unwanted and vexing consequence of the policy that both superpowers devised', also pointing out that 'limited attention has been paid to [the phenomenon]' in this regard. 'Eurocommunism and the Contradictions of Superpower Détente' in Diplomatic History, 41, 4, 2017, pp747-8.

6 See Stéphane Courtois and Marc Lazar, Histoire du Parti communiste français, Paris, PUF, 1995, pp351-55 and Serge Buj, 'El ocaso del Partido Comunista Francés: los años setenta', Carme Molinero and Pere Ysàs (eds), Las izquierdas en tiempos de transición. Valencia: Universitat de Valencia, 2016, pp50-2.

7 Paul Ginsborg, A history of contemporary Italy. Society and Politics, 1943-1988, New York: Palgrave, 2003, pp355-6; pp373-5.

8 Carme Molinero and Pere Ysàs, 'El Partido del antifranquismo (19561977)', in Papeles de la FIM. I Congreso sobre la historia del PCE, 22, 2004, pp103-126.

9 Carme Molinero and Pere Ysàs, De la hegemonía a la autodestrucción: El Partido Comunista de España (1956-1982), Barcelona, Crítica, 2017, pp111-126.

10 Charles S. Maier, 'Thirty Years After: The End of European Communism in Historical Perspective' in Fürst et al., Cambridge History of Communism, p605.

11 Ibid, p607.

12 Marc Lazar, 'El eurocomunismo, objeto de historia', in Historia del presente 18, 2011, p65.

13 See Molinero and Ysàs, De la hegemonía.

14 Donald Sassoon, One Hundred years of socialism the West European left in the twentieth century, London, I.B. Tauris, 1997, p253.

15 Marc Lazar, 'Le lente déclin du communisme', in Jean Garrigues, Sylvie Guillaume and Jean-François Sirinelli (eds), Comprendre la Ve République, Paris, PUF, 2011, pp211-231.

16 See Armen Antonian, Toward a theory of Eurocommunism, New York, Greenwood Press, 1987 and Michael Waller and Meindert Fennema (eds), Communist parties in Western Europe: decline or adaptation? Oxford, Blackwell, 1988.

17 The exceptions being general histories of the European left authored by scholars who, in search for answers to its sudden crisis, retraced 
the left's trajectory across the twentieth century. See Sassoon, One Hundred Years; Aldo Agosti, Bandiere rosse: un profilo storico dei comunisti europei, Roma, Editori riuniti, 1999; Geoff Eley, Forging democracy: the history of the left in Europe, 1850-2000, Oxford, Oxford University Press, 2002.

18 See Niall Ferguson, Charles S. Maier, Erez Manela and Daniel J. Sargent (eds.), The shock of the global: the 1970s in perspective. Cambridge, Massachusetts, The Belknap Press of Harvard University Press, 2010 and Anselm Doering-Manteuffel and Lutz Raphael, Nach dem Boom. Perspektive auf die Zeitgeschichte seit 1970, Bonn, Vandenhoeck \& Ruprecht, 2012.

19 Silvio Pons, 'The rise and fall of Eurocommunism', in Melvin P. Leffler and Odd Arne Westad (eds), The Cambridge History of the Cold War, v.3, Cambridge, Cambridge University Press, 2010, p60.

20 Lack of access to Russian archival holdings pertaining to the 1970s means that, except for the GDR, no substantial accounts of how authorities from socialist states - and especially the USSR - engaged with Eurocommunism exist. As a result, only the West's 'containment policy' has been reconstructed in detail so far.

21 See Giovanni Bernardini, 'The Federal Republic of Germany and the Resistible Rise of the Historic Compromise in Italy (1974-1978)', in Guia Migani and Antonio Varsori (eds.), Europe in the international arena during the 1970s: entering a different world, Bruxelles et al., P.I.E. Peter Lang, 2011 pp317-337; Frédéric Heurtebize, Le péril rouge Washington face à l'eurocommunisme, Paris, PUF, 2014 and Dörr, Rote Gefahr.

22 Francesco Di Palma, 'Der Eurokommunismus und seine Rezeption durch die SED (1968-1976). Einige theoretische Bemerkungen', in Jahrbuch für Kommunismusforschung 2012, pp233-248.

23 See Michele Di Donato, I comunisti italiani e la sinistra europea: il PCI e i rapporti con le socialdemocrazie (1964-1984), Roma: Carocci, 2015 and Emanuele Treglia, 'El PCE y el movimiento comunista internacional (1969-1977)', in Cuadernos de Historia Contemporánea 37, 2015, pp225-255.

24 As Silvio Pons has argued, on 'Western Communism, paradoxically, Soviet and American interests converged. For different reasons, both 
Moscow and Washington feared the PCI's reform Communism', 'The rise and fall', $\mathrm{p} 52$.

25 Dörr, Rote Gefahr, pp431-2.

26 Ibid., p44.

27 The emphasis on Eurocommunism as a 'security threat' is reflected in the work's title, namely 'The red peril' ('Die Rote Gefahr'). Incidentally, another recent study of US foreign policy officials' stance on Eurocommunism bears the same - questionable - title (Heurtebize, Le péril rouge); a coincidence that, in spite of the quality of both works, demonstrates the general slant on the topic in the literature.

28 An exception is Phil Edwards, "Rejecting all adventurism": The Italian Communist Party and the movements of $1972-79$ ' in Twentieth Century Communism 3, 2011, pp14-37. Giulia Strippoli's work on the relationship between Western European CPs and the movements emerging in 1968 (Il partito e il movimento. Comunisti europei alla prova del Sessantotto, Roma: Carocci, 2013) does not follow developments into the 1970s, when an entangled dynamic between Eurocommunist CPs and social movements came into the fold.

29 Matthew Connelly, 'Taking off the Cold War Lens: Visions of NorthSouth Conflict during the Algerian War for Independence' in The American Historical Review 105, 3, 2000, pp739-769.

30 See Peggy L. Falkenheim, 'Eurocommunism in Asia: The Communist Party of Japan and the Soviet Union' in Pacific Affairs 52, 1, pp64-77 and Wolfgang Leonhard, Eurokommunismus: Herausforderung für Ost und West, München: C. Bertelsmann, 1978. In one of the very first publications where 'Eurocommunism' is appropriated as a positive label by Italian CP members, namely the short volume of interviews and documents $A$ chi fa paura l'eurocomunismo? [Who's afraid of Eurocommunism?] Sergio Segre (ed), Rimini/Firenze, Guaraldi, 1977, there were also documents from the Japanese CP. A recent work, in turn, identifies a 'proto-Eurocommunism' in the Australian CP's 'embrace of the rising new social movements', 'parliamentary approach to socialism' and 'shift away from uncritical support of the Soviet Union' in the late 1960s. Jon Piccini, Evan Smith and Matthew Worley, 'Introduction: The history of the far left in Australia since

Twentieth Century Communism - Issue 17 
$1945^{\prime}$ in ibid (eds), The Far Left in Australia since 1945, London, Routledge, 2018, p6.

31 Barry Carr, Mexican communism, 1968-1983: eurocommunism in the Americas?, La Jolla, University of California, Centre for U.S.-Mexican Studies, 1985.

32 See Leonhard, Eurokommunismus.

33 Nikolas Dörr, 'Eurokommunismus als Teil der historischen Kommunismusforschung, Version: 1.0, in Docupedia-Zeitgeschichte, 06.01.2014, access on 10.08.2019.

34 Dörr, Rote Gefahr, pp50-1.

35 Heurtebize, 'Eurocommunism', p747.

36 Duccio Basosi and Giovanni Bernardini, 'The Puerto Rico Summit of 1976 and the End of Eurocommunism' in Leopold Nuti (ed), The Crisis of Détente in Europe. From Helsinki to Gorbachev, 1975-1985, London, Routledge, 2009, p262.

37 'Fordismus, Eurokommunismus und Neue Linke. Thesen zu Kontinuitäten und Diskontinuitäten zwischen Arbeiterbewegung und linker Szene in der BRD', in Jahrbuch für historische Kommunismusforschung 2012, p250.

38 As pointed by one reviewer, the Greek case offers a highly fertile perspective on Eurocommunism. Despite its status as a minority phenomenon in the Greek communist movement, it had wide-ranging consequences for the country's left considering the line that stretches from the breakaway Greek Communist Party (interior) through to Synapsismos and present-day Syriza. A proper assessment of the Greek contribution to the Eurocommunist debate - which should also include the work of Nicos Poulantzas - unfortunately exceeds the scope of this review.

39 Pons, 'The rise and fall', pp50-3.

40 Treglia, 'El PCE y el movimiento', p246.

41 See Bracke, Which socialism, pp323-363; Marco Di Maggio, Alla ricerca della Terza via al Socialismo: i PC italiano e francese nella crisi del comunismo (1964-1984), Napoli, Edizioni scientifiche italiane, 2014.

42 See Pons and Di Donato, 'Reform Communism', p188; Buj, 'El ocaso', p5 54

43 Treglia, 'El PCE y el movimiento', pp233-7.

44 See Andrea Donofrio, Érase una vez el eurocomunismo. Razones de 
un fracaso, Madrid, Tecnos, 2018; Emanuele Treglia, 'Un partido en busca de identidad. La difícil trayectoria del eurocomunismo español (1975-1982)', in Historia del Presente 18, 2011, pp25-42. Pons and Di Donato downplay the role of Spanish communists within Eurocommunism, terming the PCE '.... a smaller force engaged in its own country's democratic transition'. 'Reform Communism', p188. The PCE's dialog with social movements and a resurgent unionism meant that its impact in Spanish civil society was broader than its immediate sphere of influence as a party. See Molinero and Ysàs, De la hegemonia, pp60-64. Moreover, opposition to the Spanish dictatorship drew adherents across the political spectrum throughout West Europe in the 1960s and 1970s, reaching true mass status in Italy and with the PCI leading solidarity activities. See Emanuele Treglia, 'Por la libertad de España. La solidaridad italiana con el antifranquismo, 1962-1977', in Javier Muñoz Soro and Emanuele Treglia (eds), Patria, pan, amore e fantasia. La España franquista y sus relaciones con Italia (1945-1975), Granada, Comares, 2017, pp163-5, p183.

45 Penny Von Eschen, 'Locating the transnational in the Cold War' in Petra Goedde and Richard H. Immerman (eds), The Oxford Handbook of the Cold War, Oxford, Oxford University Press, 2013, p452.

46 Die rote Gefahr, p58.

47 Palmiro Togliatti, La via italiana al socialismo, Rome, Editori Riuniti,1956, pp86-7.

48 Gian Carlo Pajetta, La lunga marcia dell'internazionalismo, Rome, Editori Riuniti, 1978, p162.

49 See Jeremy Friedman, Shadow Cold War: The Sino-Soviet competition for the Third World, Chapel Hill, Univ. of North Carolina Press, 2015.

50 See Jonathan C. Brown, Cuba's revolutionary world. Cambridge, Massachusetts, Harvard University Press, 2017.

51 Gleb J. Albert, Das Charisma der Weltrevolution, Köln, Böhlau, 2017, pp55-60.

52 Andreas Wirsching, 'Some Thoughts on Communist Internationalism', in Moving the Social 55, 2016, pp39-41.

53 See Palmiro Togliatti, 'Per l'unità del movimento operaio e comunista internazionale' (1964), in Opere VI, Roma, Editori Riuniti, 1984, pp803-6.

Twentieth Century Communism - Issue 17 
54 Alessandro Santoni, 'Il Cile e il travaglio identitario del comunismo italiano', in Raffaele Nocera and Claudio Rolle Cruz (eds), Settantatré. Cile e Italia, destini incrociati. Napoli, Think Thanks, 2010, p172.

55 See Paolo Borruso, Il PCI e l'Africa indipendente: Apogeo e crisi di un'utopia socialista (1956-1989), Firenze, Le Monnier, 2009.

56 See Alessandro Santoni, Il PCI e i giorni del Cile: Alle origini di un mito politico. Carocci editore, 2008 and Onofrio Pappagallo, Verso il nuovo mondo: Il PCI e l'America Latina (1945-1973), Milano, Angeli, 2017.

57 Onofrio Pappagallo, Il PCI e la rivoluzione cubana: La "via latinoamericana al socialismo" tra Mosca e Pechino (1959-1965), Roma, Carocci, 2009, pp47-9.

58 See Marco Galeazzi, Togliatti e Tito: tra identità nazionale e internazionalismo, Roma: Carocci, 2005 and, from the same author, Il PCI e il movimento dei paesi non allineati, Milano: F. Angeli, 2011.

59 Enrico Berlinguer,'Riflessioni dopo i fatti del Cile', in Rodolfo Mechini (ed), I comunisti italiani e il Cile. Roma, Editori Riuniti,1973, p3.

60 See the excellent study by Alessandro Santoni, Il PCI e i giorni del Cile: Alle origini di un mito politico, Roma, Carocci editore, 2008.

61 Ibid., pp36-46

62 Santoni, 'Il Cile', p171 - my emphasis.

63 Marco Galeazzi, 'Le PCI, le PCF et les luttes anticoloniales (19551975)', in Cahiers d'histoire. Revue d'histoire critique 112-113, 2010 [Online], consulted on 10.08.2019.

64 See Laura Fasanaro, 'Neither in One Bloc, Nor in the Other: Berlinguer's Vision of the End of the Cold War' in Frèdéric Bozo, Marie-Pierre Rey, N. Piers Ludlow and Bernd Rother (eds.), Visions of the End of the Cold War in Europe (1945-1990), New York, Berghahn Books, 2012, pp163-176 and Valentine Lomellini, 'Dall'europposizione all'euroeuforia. La traiettoria del Comunismo Italiano nel processo di integrazione europea', in Daniele Pasquinucci and Luca Verzichelli (eds), Contro l'Europa?: i diversi scetticismi verso l'integrazione europea, Bologna, Il Mulino, 2016, pp71-92.

65 Especially in the case of the PCI and the PCE. See Alessandro Brogi, "'Westpolitik"'. Eurocommunism and the evolution of Western European Communists' positions towards European integration', in 
Lucia Bonfreschi, Giovanni Orsina and Antonio Varsori (eds), European parties and the European integration process, 1945-1992, Bruxelles et al., Peter Lang, pp144-6; Marco Galeazzi, 'Regional Détente or a New International Order? The Italian Communist Party, Non-Aligned Leaders and the Mediterranean, 1964-1980', in Calandri, Détente in Cold War Europe, pp75-87; Carlos López Gómez, 'Comunismo y europeísmo: el PCE ante la adhesión de España a la Comunidad Económica Europea' in Rafael Quirosa-Cheyrouze Muñoz et al. (eds), $V$ Congreso Internacional Historia de la Transición en España. Las organizaciones politicas, Almería, Universidad de Almería, 2011, p587.

66 Enrico Berlinguer cited in Fasanaro, 'Neither in One Bloc', p169.

67 Chiara Valentini, Berlinguer: l'eredità difficile, Roma, Editori Riuniti, 1997, p335.

68 Silvio Pons, Berlinguer e la fine del comunismo, Torino, G. Einaudi, 2006, xvii

69 Enrico Berlinguer, La questione comunista.1969-1975, Roma, Editori riuniti,1975, pp845-6.

70 Carlos Nelson Coutinho, 'A democracia como valor universal', in Encontros com a Civilização Brasileira 9, 1979, p34.

71 Victor Neves, Democracia e socialismo: Carlos Nelson Coutinho em seu tempo, Marília, Lutas anticapital, 2019, p117.

72 See Giovani Garavini, 'The Colonies Strike Back: The Impact of the Third World on Western Europe, 1968-1975', Contemporary European History 16, 3, pp299-319.

73 Basosi and Bernardini, 'The Puerto Rico Summit', p256.

74 For a highly illuminating discussion of the shifts in Italy's economic situation from the 1960s to the 1990s, with key background information for the trajectory of the PCI, see Francesco Petrini, 'Mercantilism and Class Struggle: The Italian Economy in the International Context from 1960 to 1990' in Antonio Varsori and Benedetto Zaccaria (eds.), Italy in the International System from Détente to the End of the Cold War: The Underrated Ally. Cham, Springer, 2018, pp127-160.

75 L'Unità, 11.12.1974, p7.

76 Fernando Claudín, Eurocomunismo y socialismo, Madrid: Siglo XXI, 1977, p27. The work is also available in English: Eurocommunism and Socialism, London, NLB, 1978. 
77 Andrea Donofrio, 'El eurocomunismo, ¿̨producto de la crisis económica y política de los setenta?', in Revista de estudios politicos 163, 2014, p14.

78 De la hegemonía, p134.

79 'The rise and fall', pp53

80 Sassoon, One Hundred years, p577.

81 David Harvey, A Brief History of Neoliberalism, Oxford, Oxford University Press, 2005, pp21-8; Quinn Slobodian, Globalists: the end of empire and the birth of neoliberalism, Cambridge, Mass., Harvard University Press, 2018, p18.

82 Basosi and Bernardini, 'The Puerto Rico Summit', p263

83 See Austerità: occasione per trasformare l'Italia, Roma: Ed. Riuniti, 1977.

84 Fabien Escalona, 'The heritage of Eurocommunism in the contemporary radical left', The Socialist Register, 2017, pp102-119.

85 Treglia, 'El PCE y el movimiento', p231.'Although its significance in a wider perspective was probably limited, the PCR's [i.e., the Romanian CP's - VS] support for the theses of the Western communists from inside the communist bloc did play a role in preventing the Soviet Union from isolating the West European communists'. Cezar Stanciu, 'Nicolae Ceauşescu and the origins of Eurocommunism', Communist and Post-Communist Studies 48, 1, 2015, p84.

86 As in the case of Leonhard, Eurokommunismus, pp22-5

87 See Pons and Di Donato, 'Reform Communism'.

88 Another contribution along these lines is José M. Faraldo, 'Entangled Eurocommunism: Santiago Carrillo, the Spanish Communist Party and the Eastern Bloc during the Spanish Transition to Democracy, 1968-1982', Contemporary European History, 26, 4, 2017, pp647-68.

89 Pons and Di Donato, 'Reform Communism', p196. Despite a widened scope of analysis placing Eurocommunism along an East-West axis of transfers and exchanges, the authors dismiss its impact in the Third World. While drawing attention to the universalist slant behind the PCI's Eurocommunism, they still maintain that the phenomenon's relevance to 'renewing communist political culture in non-European countries was effectively limited to Japan'; in the global South, in turn, 'anti-imperialist traditions prevented reform communism from holding sway - with the partial exception of Brazil', ibid., p190. 
90 See Bracke, Which socialism, p209

91 See Giaime Pala and Tommaso Nencioni, 'La nueva orientación de 1968. El PCE-PSUC ante la Primavera de Praga', in Maud Bracke, Alexander Höbel, Giaime Pala and Tommaso Nencioni (eds), El inicio del fin del mito soviético: Los comunistas occidentales ante la Primavera de Praga. Mataró, El Viejo Topo, 2008, pp139-201.

92 Alexander Höbel, 'El PCI en el movimento comunista, el 68 checoslovaco y la relación con el PCUS', in Bracke et al., El inicio del fin, p54

93 Pala and Nencioni, 'La nueva orientación', pp139-140; see also Lilly Marcou, Le mouvement communiste international depuis 1945. Paris, PUF, 1980, p102

94 See Bracke, Which socialism, p323

95 Höbel, 'El PCI en el movimento', p89

96 As Giulia Strippoli has argued, even if the gap between the student movement and CPs was never successfully bridged, the interaction between them and the debates the events generated within the parties were both key to their dynamic in the post-68 years. Il partito e il movimento, pp171-7.

97 'Preface: Was there a "global 1968"'? in Chen Jian et al. (eds), The Routledge handbook of the global sixties: Between protest and nationbuilding. London/New York, NY, Routledge, 2018, xxi.

98 Ibid., xxi-xxii

99 Geoff Eley, Forging, p416.

100 While I will only briefly discuss the evidence of this encounter in 1970 s Italy (on which there is a growing literature I cannot cite here for lack of space), the same cross-pollinizing pattern is found in other contexts where Eurocommunism had a significant impact, from Spain to Brazil and all the way to Australia. See, respectively, Mónica Moreno Seco, 'A la sombra de Pasionaria. Mujeres y militancia comunista (1960-1982)', in María Dolores Ramos (ed), Tejedoras de ciudadanía. Culturas politicas, feminismos y luchas democráticas en España, Málaga, Universidad de Málaga, 2014, pp257-282, Raquel Soihet, 'Do Comunismo ao Feminismo: a trajetória de Zuleika Alambert', in Cadernos Pagu 40, 2013, pp169-195 and Margaret Penson, Breaking the Chains: Communist Party Women and the Women's Liberation Movement 1965-1975, Broadway, NSW, 
Breaking the Chains Collective, 1999. The French case, due to a more orthodox PCF, has its own specificities, but would still merit closer examination considering the strength of the feminist uprising the country experienced post-1968 and its relevance for the ensuing global feminist wave.

101 Maud Bracke, Women and the reinvention of the political. Feminism in Italy, 1968-1983, New York, NY, Routledge 2014, p211.

102 The referendum was called in response to pressure from Catholic groups aiming to revert a law passed in 1970 that 'made no-fault divorce legal and relatively easy to obtain by men and women on an equal basis'. Bracke, Women and the reinvention, p74. It put the PCI in a delicate position considering it set the party on a collision course with Christian Democrats, precisely as the communists' main political goal was to cooperate with them as per the 'historic compromise'.

103 Ibid., pp89-91.

104 Ibid., p4.

105 Ibid., p79.

106 Ibid., p87.

107 Laura Lilli, 'La doppia militanza come esistenza', in Chiara Valentini and Laura Lilli (eds), Care compagne: Il femminismo nel PCI e nelle organizzazioni di massa, Roma, Riuniti, 1979, p10.

108 Ibid.

109 Ibid., p31.

110 in La questione femminile: Intervista col PCI, Milano: Bompiani, 1976, p10.

111 Women and the reinvention, $\mathrm{p} 76$.

112 Ravaioli, La questione femminile, p10.

113 'Feministinen und KPI, ein eigenartiges Verhältnis', in Rossana Rossanda, Auch für mich. Aufsätze zu Politik und Kultur, Hamburg, Argument, 1994, p45.

114 Despite my best efforts to keep up to date with the latest contributions on Eurocommunism, there are significant works that I was not able to incorporate into this review either because of how recently they were published or because they have become accessible to me too late into the writing process. Two works which reviewers have drawn attention 
too are, Ioannis Balampanidis, Eurocommunism: From the Communist to the Radical European Left, London, Routledge, 2018 and Mike Makin-Waite, Communism and democracy: history, debates and potentials, London, Lawrence \& Wishart, 2017.

Twentieth Century Communism - Issue 17 